\section{RELEASE BeHAVIOR OF DICHLORPROP FROM ZN/AL-LDH-DICHLORPROP NANOCOMPOSITE INTO ChloRIDE, CARbonate AND PhOSPhate SOLUTIONS}

Norhayati Hashima,b*, Sharifah Norain Mohd Sharifa, Zuhailimuna Mudaa, Illyas Md Isaa,b, Suriani Abu Bakarb,c, Noorshida Mohd Alia, Mohd Zobir Husseind, Mazidah Mamate

aDepartment of Chemistry, bNanotechnology Research Centre, cDepartment of Physics, Faculty of Science and Mathematics, Universiti Pendidikan Sultan Idris, 35900 Tanjong Malim, Perak, Malaysia

dMaterials Synthesis and Characterization Laboratory, Institute of Advanced Technology, Universiti Putra Malaysia 43400 UPM Serdang, Selangor, Malaysia

eFoundation of Science Study Centre, Universiti Malaysia Terengganu, 21030 Kuala Terengganu, Terengganu, Malaysia
Article history

Received

2 July 2018

Received in revised form

10 October 2018

Accepted

1 November 2018

Published online

18 February 2019

*Corresponding author norhayati.hashim@fsmt.upsi.edu.my

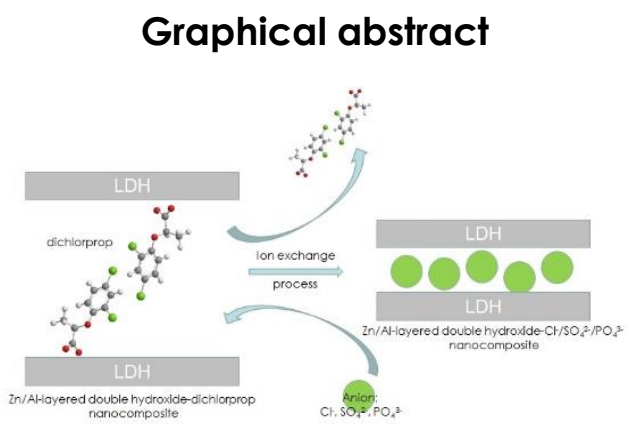

\begin{abstract}
A release study of dichlorprop phenoxyherbicides from the interlayer of a $\mathrm{Zn} / \mathrm{Al}$ layered double hydroxide-dichlorprop nanocomposite was performed with various concentrations of sodium chloride, sodium carbonate and sodium phosphate and a mixture of sodium chloride, sodium carbonate and sodium phosphate in aqueous solution. The release study of dichlorprop showed that release is dependent on the concentration of the aqueous solution. The accumulated release percentage of dichlorprop phenoxyherbicides into the solution was found to be higher in solutions containing carbonate, phosphate, and a mixture of carbonate or phosphate anions. Confirmation of the release process was confirmed by the PXRD pattern of the powder recovered from highly concentrated solutions of sodium chloride, sodium carbonate, and sodium phosphate with basal spacing of $7.8 \AA, 7.6 \AA$ and $7.4 \AA$, is due to chloride, carbonate, and phosphate intercalation, respectively. The kinetic study revealed that dichlorprop release into sodium carbonate and sodium phosphate solutions is governed by pseudo-second order kinetics, while release into sodium chloride solution is governed by parabolic diffusion. This study shows that a layered double hydroxide might be used as a host for the controlled release of the phenoxyherbicide dichlorprop.
\end{abstract}

Keywords: Dichlorprop, Zn/Al-LDH-dichlorprop, Nanocomposite, Release Behavior 


\begin{abstract}
Abstrak
Satu kajian pelepasan fenoksiherbisida diklorprop daripada ruang antara lapisan nanokomposit hidroksida Zn/Al lapisan berganda dilakukan dalam pelbagai kepekatan larutan akueus natrium klorida, natrium karbonat dan natrium fosfat dan campuran larutan akueus natrium klorida, natrium karbonat dan natrium fosfat. Kajian pelepasan diklorprop menunjukkan bahawa ia adalah bergantung kepada kepekatan larutan akueus. Peratusan pelepasan terkumpul fenoksiherbisida diklorprop ke dalam larutan campuran didapati lebih tinggi berbanding dengan dalam larutan yang mengandungi karbonat, fosfat dan campuran karbonat atau fosfat anion. Pengesahan kepada proses pelepasan disahkan dengan corak PXRD bagi serbuk hasil yang diperolehi pada kepekatan tertinggi larutan natrium klorida, natrium karbonat dan natrium fosfat menunjukkan jarak basal $7.8 \AA$, $7.6 \AA$ dan $7.4 \AA$ masing-masing yang disebabkan oleh interkalasi klorida, karbonat dan fosfat. Kajian kinetik mendedahkan bahawa pelepasan diklorprop ke dalam larutan natrium karbonat dan natrium fosfat dikawal oleh tertib kedua pseudo manakala pelepasan ke dalam larutan natrium klorida dikawal oleh peresapan parabolik. Kajian ini menunjukkan bahawa lapisan berganda hidroksida mungkin boleh digunakan sebagai tuan rumah untuk rumusan lapisan terkawal fenoksiherbisida, diklorprop.

Kata kunci: Diklorprop, Zn/Al-LDH-Diklorprop, Nanokomposit, Tingkah laku pelepasan
\end{abstract}

(c) 2019 Penerbit UTM Press. All rights reserved

\subsection{INTRODUCTION}

Herbicides are used to kill unwanted plants in the agriculture sector. However, the heavy use of herbicides in this sector has given rise to serious underground water contamination and human health problems. To overcome this problem, it is important to develop new herbicide formulations that are safer, highly effective, and low cost. Layered materials, especially layered double hydroxides (LDH), are suitable nanomaterials for the preparation of controlled release formulation (CRF) of herbicides due to their unique host-guest type structure [1]. Research in controlled release formulations has attracted considerable attention in recent years, especially in the pharmaceutical [2] and environmental [3] industries. For example, studies on the release of different non-steroidal antiinflammatory drugs (NSAIDs) intercalated between $\mathrm{Mg} / \mathrm{Al} / \mathrm{Fe}$-hydrotalcite interlayers showed slow dissolution of the drug in solution [4]. Meanwhile, the simultaneous release of both 2-(3chlorophenoxy)propionate (CPPA) and 4-(2,4dichlorophenoxy)butyrate (DPBA) herbicides from $\mathrm{Zn} / \mathrm{Al}-\mathrm{LDH}$ into the release media was found to be fitted by a pseudo second-order equation [5]. In both of these studies, LDH demonstrated potential to be applied as a layered host material for drug and herbicide release. $\mathrm{LDH}$ as a CRF material in the environment may significantly reduce water contamination in the agriculture sector; for example, the use of a CRF may restrict herbicide movement through the groundwater and soil. As reported by Bruna [6], an organohydrotalcite layered material has been used as a novel host material for the slow release of terbuthylazine, a widely applied agricultural herbicide. The synthesized herbicide (with additional CRF formulation) was compared to a standard commercial formulation of the herbicide. The results showed the promising capacity of the organohydrotalcite layered material to serve as a suitable support for herbicide slow release formulations with the aim of reducing the adverse effects derived from rapid transport losses of the chemical once applied to soils.

The structure of LDH is made up of positively charged edge sharing octahedra, which forms host layers with a brucite-like structure. The combination of divalent and trivalent cations in the LDH structure produces excessive positive charges in the interlayer, which need to be balanced by the presence of the interlayer anions. LDH can be represented by a general formula, $\left[\mathrm{M}^{2+}(1-x) \mathrm{M}^{3+}{ }_{x}(\mathrm{OH})_{2}\right]\left[\mathrm{A}^{n-}(\mathrm{x} / \mathrm{n})\right] \cdot \mathrm{zH}_{2} \mathrm{O}$ with $\mathrm{M}^{2+}$ is a metal such as $\mathrm{Mg}^{2+}, \mathrm{Zn}^{2+}, \mathrm{CO}^{2+}, \mathrm{Ni}^{2+}, \mathrm{Mn}^{2+}$ and $\mathrm{M}^{3+}$ is a trivalent metal ion such as $\mathrm{Al}^{3+}, \mathrm{Fe}^{3+}, \mathrm{Cr}^{3+}$, $\mathrm{Ga}^{3+}, \mathrm{Ni}^{3+}, \mathrm{Mn}^{3+}[1,7] . \mathrm{A}^{\mathrm{n}-}$ is an interlayer anion such as $\mathrm{CO}_{3}{ }^{2-}, \mathrm{NO}^{3-}, \mathrm{SO}_{4}{ }^{2-}$ or $\mathrm{Cl}^{-}, \mathrm{x}$ is the charge density, that is, the molar fraction of $\mathrm{M}^{3+} /\left(\mathrm{M}^{2+}+\mathrm{M}^{3+}\right)$, and $n$ represents the charge of the interlayer anion [8]. In this study, we report on the controlled release properties of a phenoxyherbicide, dichlorprop anion (2-(2,4-dichlorophenoxy) propionic acid) from DPPADI (Zn/Al-LDH-dichlorprop nanocomposites synthesized by a co-precipitation method), and DPPAEX (Zn/AlLDH-dichlorprop nanocomposites synthesized by an ion exchange method) nanocomposites into sodium chloride, sodium carbonate, and sodium phosphate solutions. The release of dichlorprop into a mixture of chloride, carbonate, and phosphate solution was also assessed to determine the effect of single, binary and ternary anions toward the release behaviour of phenoxyherbicides. 


\subsection{METHODOLOGY}

Synthesis and characterization of $\mathrm{Zn} / \mathrm{Al}-\mathrm{LDH}-$ dichlorprop (DPPADI and DPPAEX) has been done in a previous report [9]. The controlled release study into aqueous solution was done at salt concentrations of $0.001 \mathrm{M}-0.008 \mathrm{M}$ in solution (sodium chloride, sodium carbonate and sodium phosphate). A Perkin Elmer UV-Vis spectrophotometer equipped with Lambda 35 software was used to determine the release of the anion from the metal hydroxide layers of the nanocomposite in three different salt solutions. A 6.0 mg sample was weighed and put in contact with 3 $\mathrm{mL}$ of aqueous solutions of sodium chloride, sodium carbonate, and sodium phosphate in order to study the effect of the different salts toward the release of the anion. The concentration of the anion released into the solution was continuously monitored, and measured by UV-Vis spectrophotometry. The percentage of accumulated release from the nanocomposites was calculated using the equation of zeroth order $(x=t+c$, where $x$ is the percentage release of the intercalated LP anions at time $t, c$ is a constant). The release of DPPADI and DPPAEX were fitted into four kinetic order models: zeroth order, first order, pseudo-second order, and parabolic diffusion.

A sample of $0.5 \mathrm{~g}$ was put in contact with $500 \mathrm{~mL}$ of each of the following solutions: $0.008 \mathrm{M}$ sodium chloride, sodium carbonate, and sodium phosphate. The content was vigorously stirred at room temperature for various periods of time, and the slurry was then centrifuged, dried in an oven at $70^{\circ} \mathrm{C}$, ground and kept in sample bottles for powder X-ray diffraction (PXRD) characterization. The PXRD patterns were recorded on a ShimadzU XRD-6000 Xray diffractometer in the $2 \theta$ range of $2^{\circ}$ to $60^{\circ}$ using filtered Cu-Ko radiation ( $\lambda=0.1540562 \mathrm{~nm}$ ) at $40 \mathrm{kV}$ and $20 \mathrm{~mA}$ with $2^{\circ} \mathrm{min}^{-1}$.

\subsection{RESULTS AND DISCUSSION}

\subsection{Controlled Release Study}

Figures 1,2 and 3 show the release profile of dichlorprop from the DPPADI and DPPAEX nanocomposites into four different concentrations of sodium chloride, sodium carbonate and sodium phosphate aqueous solutions, respectively.

The fast release of the dichlorprop anion from DPPADI and DPPAEX nanocomposites were observed in the first 0-150 minutes for the sodium carbonate and sodium phosphate solutions, followed by slow release before saturated release was achieved. For sodium chloride, slower release was observed; it was concentration-dependent and the accumulated saturated maximum was achieved at around 4000 minutes for both the DPPADI and DPPAEX nanocomposites. Ion exchange took place in the release reaction due to the higher affinity of carbonate and phosphate ion toward the dichlorprop anion. As reported by Sato and Okuwaki [10] and Ulibarri et al. [11], monovalent anion pesticides have low affinity toward layered materials compared to carbonate and phosphate anions for the exchange process. Therefore, intercalated dichlorprop was exchanged with carbonate and phosphate anions, and subsequently released into the solution.

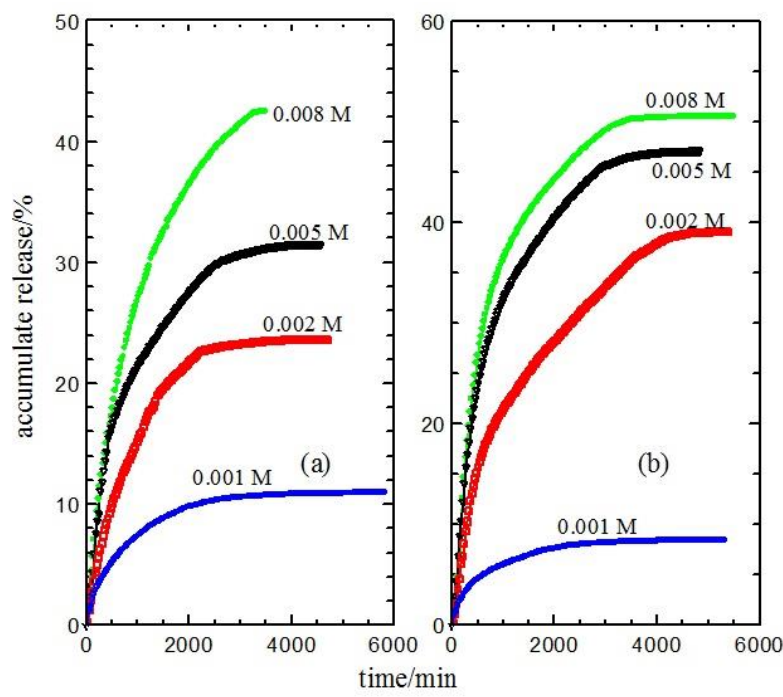

Figure 1 Release profile of DPPA from the interlamellae of the (a) DPPADI and (b) DPPAEX nanocomposites into aqueous solutions containing various concentrations of $\mathrm{NaCl}$

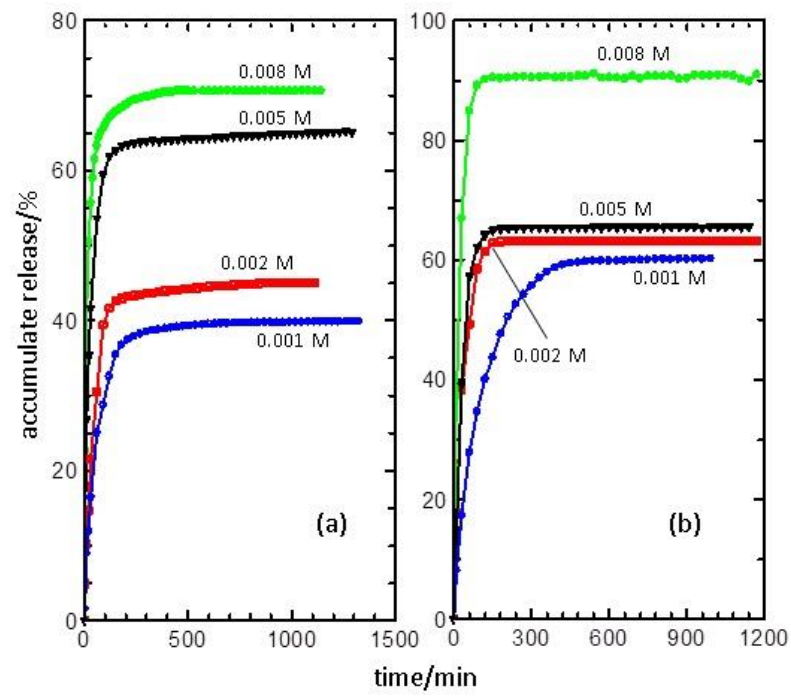

Figure 2 Release profile of DPPA from the interlamellae of the DPPADI (a) and DPPAEX (b) nanocomposites into aqueous solutions containing various concentrations of $\mathrm{Na} 2 \mathrm{CO} 3[9]$ 


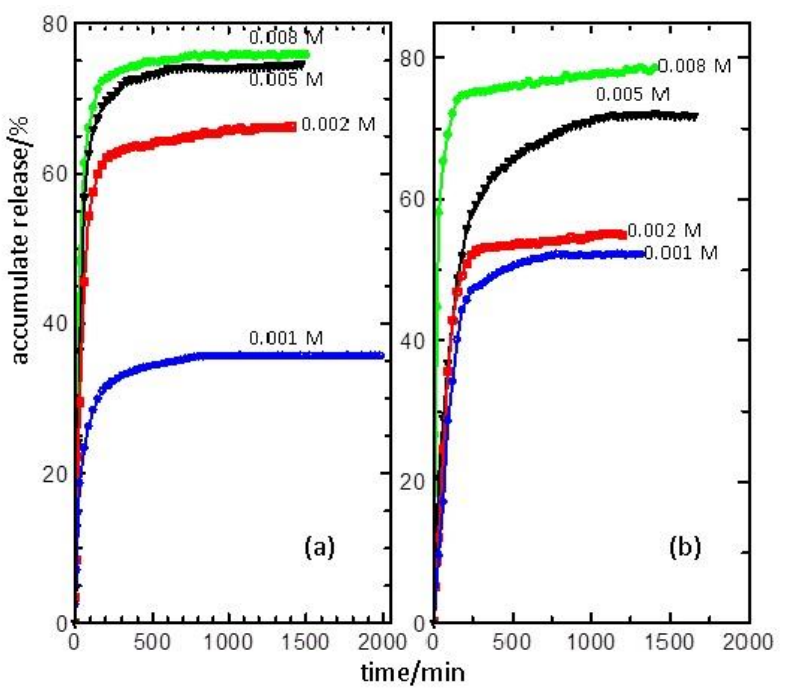

Figure 3 Release profile of DPPA from the interlamellae of the (a) DPPADI and (b) DPPAEX nanocomposites into aqueous solutions containing various concentrations of $\mathrm{Na} 3 \mathrm{PO} 4$

Deintercalation of dichlorprop was hindered by the new formation of layered double hydroxide at the outer layer of particle, as the release of guest was found to occur in a controlled manner. At the same time, the replacement of dichlorprop in the interlayer of LDH was mediated by carbonate, or phosphate anions from the solution. The percentage of dichlorprop anion release from both nanocomposites into the sodium chloride, sodium carbonate and sodium phosphate solutions is shown in Table 1. The slower release of dichlorprop from both DPPADI and DPPAEX into sodium chloride corresponds to the lower affinity of chloride anions toward LDH inorganic interlamellae compared to carbonate and phosphate anions. In addition, chloride anions are small monovalent anions that have less affinity than carbonate and phosphate ion for the ion exchange process in solution, as reported by Hussein [12].

For both nanocomposites, the release profiles of the dichlorprop anion from the interlayer of the nanocomposite showed higher amounts of maximum accumulated release from the DPPAEX nanocomposite compared to the DPPADI nanocomposite for all concentrations of sodium carbonate followed by sodium phosphate and sodium chloride. The orientation and arrangement of the anion within the inter gallery matrix for both nanocomposites were calculated to be the same value, $16.7 \AA$ (Figure 4) [9]. The differences may be due to the crystallinity of the materials, which affects the amount of dichlorprop readily available to be released. The nanocomposite preparation method is the main factor that determines the physicochemical properties of the resulting materials, thus related to surface properties and the release behaviour of the guest anion.

Table 1 Percentage release (\%) of DPPA anion into various solutions

\begin{tabular}{|c|c|c|c|c|c|c|}
\hline \multicolumn{7}{|c|}{ DPPA anion } \\
\hline \multirow[b]{2}{*}{ (M) } & \multicolumn{2}{|c|}{$\begin{array}{c}\mathrm{NaCl} \\
\text { solution }\end{array}$} & \multicolumn{2}{|c|}{$\begin{array}{l}\mathrm{Na}_{2} \mathrm{CO}_{3} \\
\text { solution }\end{array}$} & \multicolumn{2}{|c|}{$\begin{array}{l}\mathrm{Na}_{3} \mathrm{PO}_{4} \\
\text { solution }\end{array}$} \\
\hline & $\begin{array}{c}\text { DPPA } \\
\text { DI }\end{array}$ & $\begin{array}{c}\text { DPPA } \\
\text { EX }\end{array}$ & $\begin{array}{c}\text { DPPA } \\
\text { DI }\end{array}$ & $\begin{array}{c}\text { DPPA } \\
\text { EX }\end{array}$ & $\begin{array}{c}\text { DPPA } \\
\text { DI }\end{array}$ & $\begin{array}{c}\text { DPPA } \\
\text { EX }\end{array}$ \\
\hline 0.001 & 11 & 8 & 38 & 59 & 35 & 51 \\
\hline 0.002 & 23 & 38 & 45 & 63 & 65 & 54 \\
\hline 0.005 & 31 & 46 & 65 & 65 & 74 & 72 \\
\hline 0.008 & 42 & 50 & 78 & 91 & 76 & 77 \\
\hline
\end{tabular}

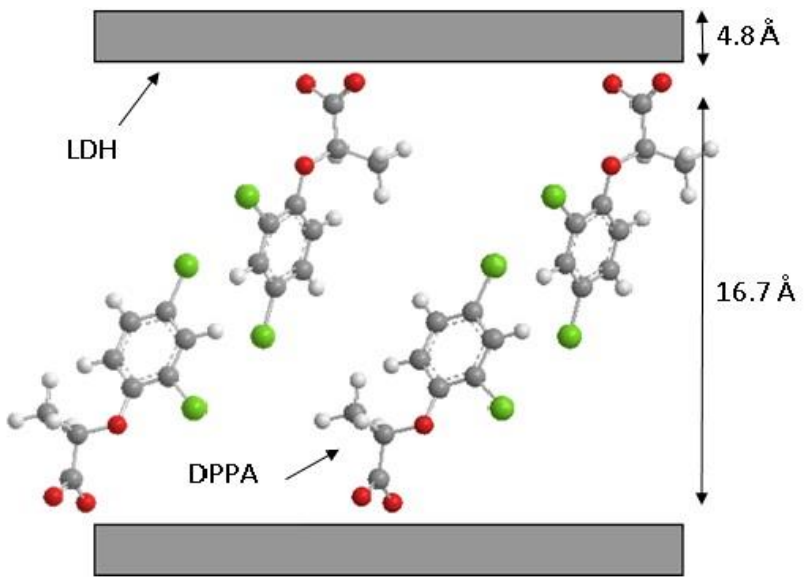

Figure 4 The proposed arrangement of DPPA intercalated into LDH inorganic interlayer for both DPPADI and DPPAEX nanocomposites [9]

In order to confirm results of the release study, solid material residues at the beginning of guest release, at $50 \%$ of accumulated release and maximum release time in the chloride, carbonate and phosphate solutions at higher concentrations were dried, and their PXRD pattern recorded for both the DPPADI and DPPAEX nanocomposites (Figure 5). At the beginning of the release time for DPPADI in all three solutions, the PXRD patterns were quite similar with basal spacing in the range of $21.3 \AA$ to $21.8 \AA$ corresponding to diffraction by the 003 plane of the layered system containing dichlorprop in the interlayers. A similar result was obtained from the DPPAEX nanocomposite pattern release into the chloride, carbonate and phosphate solutions. The difference in the intensity of the intercalation peak among these patterns corresponded to less crystallinity of the nanocomposite as the ion exchange process started in the solution. For the pattern at $50 \%$ accumulated release, the intensity of the intense and sharp peak of 003 reflections for the 
nanocomposite decreased. At the same time, reflections corresponding to the medium anion increased, which led to an increase in the medium anion intercalated in the layers of the layered double hydroxide. This occurred as a result of the exchange of the intercalated dichlorprop with the chloride, carbonate and phosphate anions present in the medium. It may also be due to the dissolution of inorganic LDH, and the collapse of the inorganic layer [12].

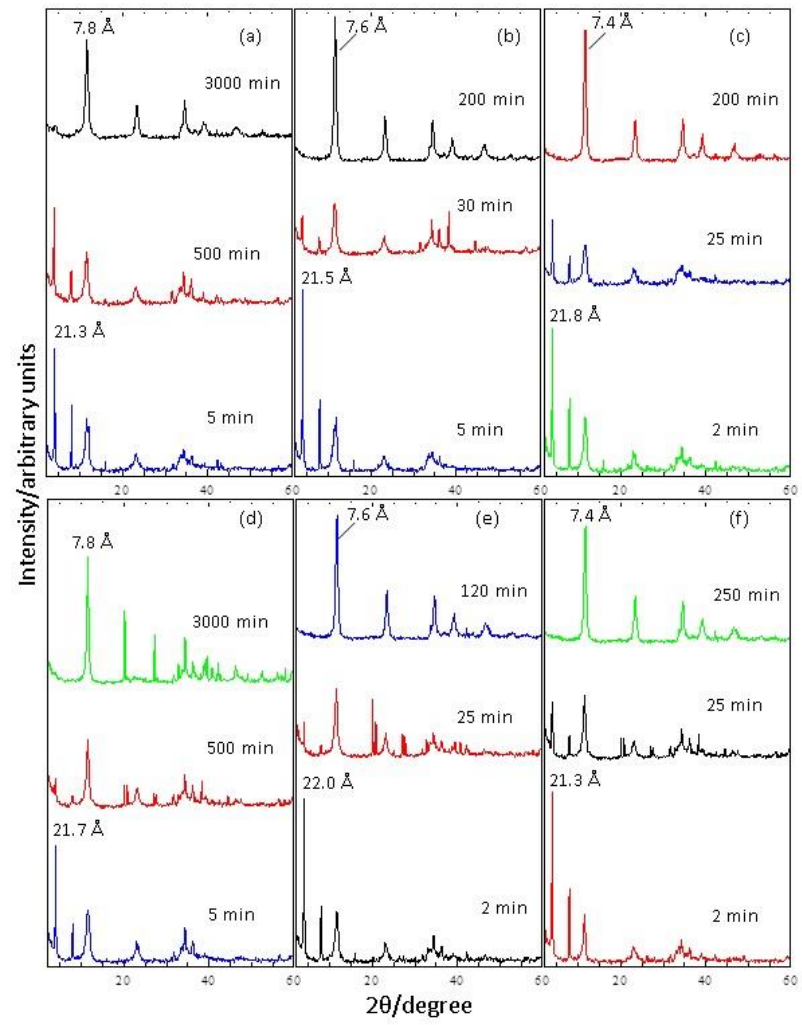

Figure 5 PXRD patterns for the samples recovered from various aqueous solutions of (a) chloride, (b) carbonate, and (c) phosphate for DPPADI and (d) chloride, (e) carbonate, and (f) phosphate for DPPAEX

The PXRD patterns for the samples dried after release achieved equilibrium show a sharp and intense peak of 003 reflections, which indicated high crystallinity of the material. The basal spacing of 7.8 $\AA$, $7.6 \AA$, and $7.4 \AA$ for that peak referred to chloride, carbonate and phosphate anions intercalated in the interlayer of $\mathrm{LDH}$. The remaining intercalation peak at a lower $2 \theta$ angle was observed as an indication that not all dichlorprop in the interlayers of the nanocomposite was released into the solution via the ion exchange process. The different release times at equilibrium in different solutions was due to the differences of density anion toward the interlamellae of LDH. In the dichlorprop release study, carbonate anions showed higher density toward LDH compared to chloride and phosphate anions, which is in agreement with previous work by Hussein [12].

\subsection{Kinetic Study}

In order to study the release kinetics of the dichlorprop anion, data obtained from the release profile for dichlorprop from its nanocomposite into sodium chloride, sodium carbonate and sodium phosphate solutions were fitted to several kinetic models, including zeroth order (Equation (i)) [13], first order (Equation (ii)) [14], pseudo-second order (Equation (iii)) [15], and parabolic diffusion (Equation (iv)) [16]. The equation for each kinetic model is as follows:

$$
\begin{aligned}
& x=t+c \\
& \log \left(1-M_{i} / M_{f}\right)=t+c \\
& t / M_{i}=1 / M^{2}+t / M_{f} \\
& M_{i} / M_{f}=k t^{0.5}+c
\end{aligned}
$$

where $\mathrm{x}$ is the percentage release of the intercalated dichlorprop anions at time $t, c$ is a constant, $M i$ represents the initial concentration of the dichlorprop, and $M_{f}$ is the final concentration of the dichlorprop. Table 2 and Table 3 show a comparison between correlation coefficients $\left(r^{2}\right)$ of the four models kinetic models.

As shown in Figure 6 (b) and (c)) and Figure 7 (b) and (c), dichlorprop release into sodium carbonate and sodium phosphate solutions from both DPPADI and DPPAEX nanocomposites was governed by pseudo-second order kinetics, while parabolic diffusion was the best fit for dichlorprop release into sodium chloride (see Figure 6 (a) and Figure 7 (a)). The correlation coefficients $\left(r^{2}\right)$, under the experimental conditions described earlier, indicate that the pseudo-second order model was the best to describe the release behaviour kinetics of dichlorprop from both DPPADI and DPPAEX nanocomposites in sodium carbonate and sodium phosphate solutions. However, parabolic diffusion was found to suit the release behaviour of dichlorprop from both the DPPADI and DPPAEX nanocomposites in sodium chloride solution.

It should be stated that release of the guest anion into the carbonate and phosphate aqueous solutions from the inorganic LDH interlamellae involved the dissolution and diffusion of nanocomposite during ion exchange between the intercalated anions in the interlamellae host [17]. However, the release of the guest anion into the chloride aqueous solution was controlled by intraparticle diffusion or surface diffusion. Therefore, it could be suggested that the results indicate that external surface diffusion or intraparticle diffusion via ion exchange is the ratedetermining step in the release process [18]. 

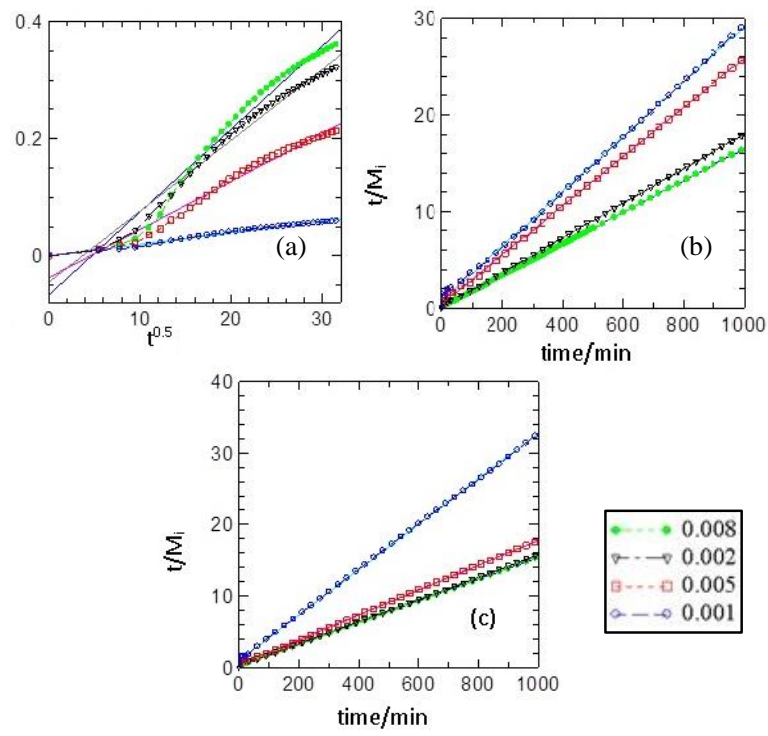

Figure 6 Fitting of the data of dichloroprop anions from DPPADI nanocomposite to the (a) parabolic diffusion in $\mathrm{NaCl}$ solution, (b) pseudo-second order kinetic in $\mathrm{Na} 2 \mathrm{CO} 3$ solution, and (c) pseudo-second order kinetic in Na3PO4 solution, containing various concentration of $0.008 \mathrm{~mol} \mathrm{~L}-1$, $0.002 \mathrm{~mol} \mathrm{~L}-1,0.005 \mathrm{~mol} \mathrm{~L}-1$ and $0.001 \mathrm{~mol} \mathrm{~L}-1$ at $\dagger=0-1000$ $\min$
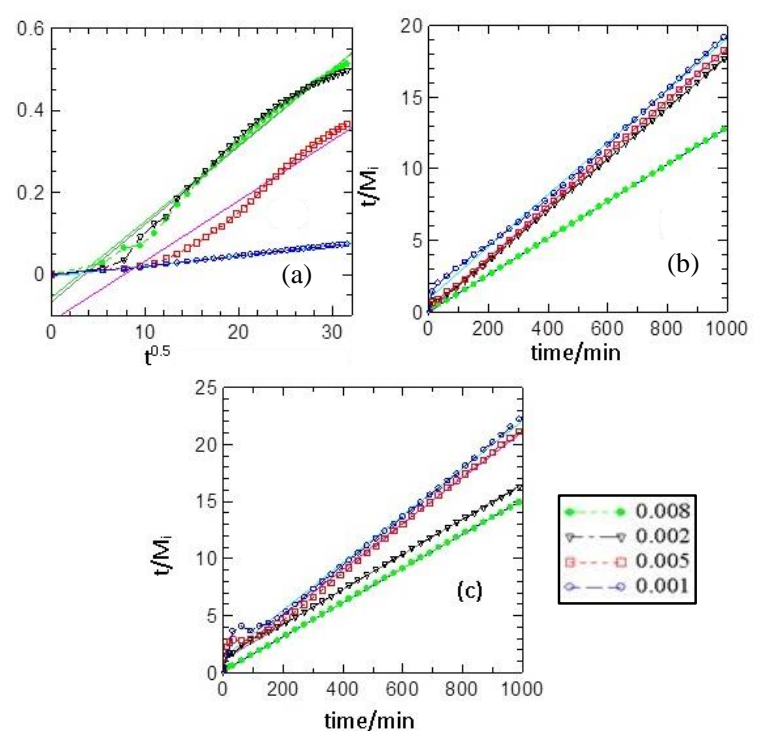

Figure 7 Fitting of the data of dichloroprop anions from DPPAEX nanocomposite to the (a)parabolic diffusion in $\mathrm{NaCl}$ solution, (b) pseudo-second order kinetic in $\mathrm{Na} 2 \mathrm{CO} 3$ solution, and (c) pseudo-second order kinetic in Na3PO4 solution containing various concentration of $0.008 \mathrm{~mol} L-1$, $0.002 \mathrm{~mol} \mathrm{~L}-1,0.005 \mathrm{~mol} \mathrm{~L}-1$ and $0.001 \mathrm{~mol} \mathrm{~L}-1$ at $\dagger=0-1000$ $\min$

\subsection{Release Study of Dichlorprop into Mixture of Aqueous Solutions}

Figure 8 (a) and (b) show the profile release of Zn/AlLDH-dichlorprop synthesized by direct coprecipitation and indirect ion exchange methods. A solution containing chloride-carbonate-phosphate anions allowed a high level of saturated release of DPPADI with a percentage release of $88 \%$. DPPAEX showed that the solution containing carbonate anions allowed high saturated release of dichlorprop with a value of $90 \%$. For both nanocomposites, rapid release of dichlorprop was observed in the initial 20 minutes for all solutions except for the solutions containing chloride anions.

The percentage release of dichlorprop from the DPPADI nanocomposite in carbonate-phosphate, chloride-phosphate, chloride-carbonate, carbonate and phosphate solutions were $74,60,59,71$ and $76 \%$, respectively. However, 86, 72, 50, 66 and $76 \%$ saturated release of dichlorprop from the DPPAEX nanocomposite was achieved in the solutions containing chloride-carbonate-phosphate, carbonate-phosphate, chloride-phosphate, chloridecarbonate and phosphate anions; this was mostly achieved in 150 minutes. Saturated release of dichlorprop from both nanocomposites into the chloride solution was $42 \%$ (DPPADI) and $50 \%$ (DPPAEX) with a slower initial rate compared to the other solutions. The release orders of dichlorprop into the solution are summarized and shown in Table 4.

As shown in Figure 8 (a), the ternary system showed a high percentage of accumulated release of dichlorprop anions from the DPPADI nanocomposite compared to the other systems. This was due to the existence of a combination of carbonate and phosphate ions with strong affinity to maximize interaction with the surrounding positive charge of the interlayer of LDH. In the binary systems, as expected, the solution that combined carbonate and phosphate ions showed a higher accumulated release percentage, which corresponded to the high affinity of carbonate toward LDH, and the high density of phosphate ions in the exchange process. The other binary solutions, chloride-carbonate and chloride-phosphate, showed a low accumulated release percentage, which could be due to the low ion exchange affinity of chloride toward the interlayer of the inorganic interlamellae [19]. For the single systems, the phosphate solution showed the highest accumulated release percentage of dichlorprop compared to carbonate and chloride. This could be due to the multiple hydrolysis of phosphate, with the existence of tertiary phosphate that has a high charge density in the solution that may have increased the ion exchange process in the replacement of dichlorprop from the interlayer [20]. 


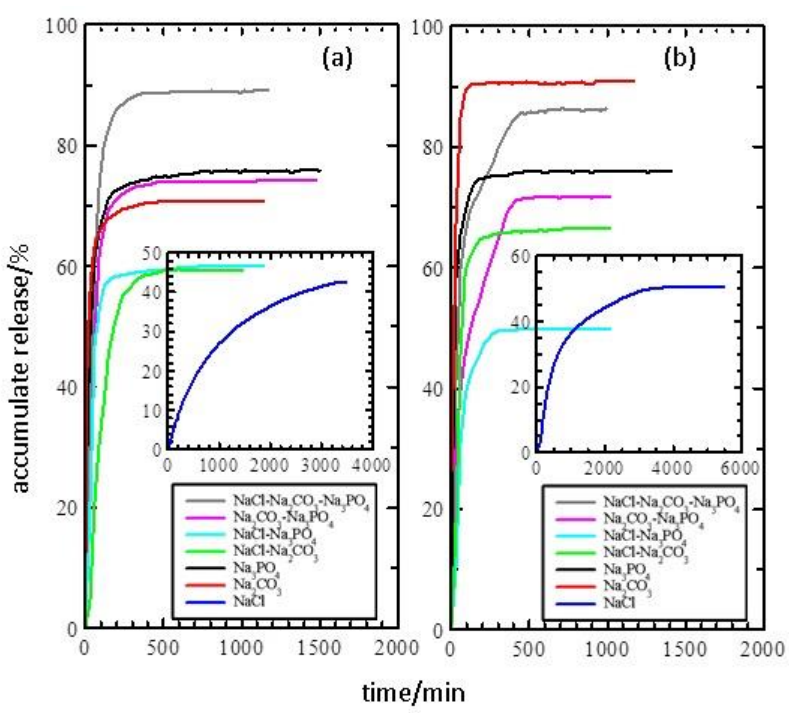

Figure 8 Release profile of DPPA from the interlamellae of the nanohybrids (a) DPPADI and (b) DPPAEX into mixture aqueous solutions

The accumulated release order of dichlorprop from the DPPAEX nanocomposite in the single system carbonate, phosphate and chloride solutions was similar to dichlorprop release from its nanocomposite, DPPAEX (Figure 8 (b)). Carbonate solution showed high percentage values due to the high affinity of carbonate anions toward the brucite-type interlayer compared to phosphate and chloride anions. The binary system containing carbonate and phosphate ions showed the highest accumulated release percentage compared to carbonate or phosphate combined with chloride, due to the low charge density of chloride that may have inhibited the ion exchange process in the solution. Carbonates and phosphates are known to have a high affinity toward LDH and a high charge density compared to chloride [21]. Therefore, carbonate and phosphate anions can be easily exchanged with the intercalated anion, i.e., dichlorprop in the ion exchange process.

For the ternary system of chloride, carbonate and phosphate, the release percentage value is lower than that of the carbonate single system, but higher than the binary, phosphate and chloride single systems. This could be due to the presence of multiple anions. Carbonate has high affinity toward LDH and phosphate has a high charge density and a maximum orientation for interaction with the positively charged layer compared to the binary, phosphate and chloride single systems. The low value of accumulated release for the ternary system compared to the carbonate single system may be due to the existence of lower affinity chloride in the system that may have inhibited the accumulated release, thus slowing down the ion exchange process. Generally, the accumulated release of dichlorprop from both DPPADI and DPPAEX nanocomposites in various solutions is dominated by the existence of phosphate or carbonate anions in the solution. However, the existence of chloride anions in the solution decreases the percentage values of accumulated release.

\subsection{CONCLUSION}

A release study of the guest ion from $\mathrm{Zn} / \mathrm{Al}-\mathrm{LDH}$ dichlorprop nanocomposites synthesized using direct co-precipitation and ion exchange methods was done in various concentrations of sodium chloride, sodium carbonate and sodium phosphate aqueous solutions. It was found that the accumulated phenoxyherbicide release into aqueous solution increases with a higher initial concentration and contact time. The accumulated release percentage of the phenoxyherbicide into solutions is in the order of: sodium carbonate $>$ sodium phosphate $>$ sodium chloride and a mixture of carbonate and phosphate solutions. The release profiles of the nanocomposite synthesized using the ion exchange method showed a higher maximum accumulated release of the phenoxyherbicide in all solutions compared to the nanocomposite synthesized using the coprecipitation method.

The release behaviour of dichlorprop from both the DPPADI and DPPAEX nanocomposites into sodium carbonate and sodium phosphate solutions was governed by pseudo-second order kinetics. For both the DPPADI and DPPAEX nanocomposites, the release behaviour of dichlorprop into sodium chloride solution was governed by parabolic diffusion. The effect of single, binary and ternary anions from sodium chloride, sodium carbonate and sodium phosphate during controlled release was assessed for the phenoxyherbicide nanocomposite. The solutions containing a mixture of carbonate and phosphate anions showed high initial release of phenoxyherbicide anions due to the high affinity of the incoming anions toward LDH. 
Table 2 Rate constants, half-life $\left(t_{1 / 2}\right)$ and correlation coefficients obtained from the fitting of the data of DPPA release from DPPADI into $\mathrm{NaCl}, \mathrm{Na}_{2} \mathrm{CO}_{3}$ and $\mathrm{Na}_{3} \mathrm{PO}_{4}$ solutions [9]

\begin{tabular}{|c|c|c|c|c|c|c|c|}
\hline \multicolumn{8}{|c|}{ DPPADI } \\
\hline \multirow[t]{2}{*}{$\begin{array}{c}\mathrm{NaCl} \\
\text { Concentration } \\
\left(\mathrm{mol} \mathrm{L}^{-1}\right)\end{array}$} & $\begin{array}{l}\text { Zeroth } \\
\text { Order }\end{array}$ & $\begin{array}{l}\text { First } \\
\text { Order }\end{array}$ & $\begin{array}{l}\text { Pseudo- } \\
\text { second } \\
\text { Order }\end{array}$ & \multicolumn{4}{|c|}{ Parabolic Diffusion } \\
\hline & \multicolumn{3}{|c|}{$r^{2}$} & $r^{2}$ & $\begin{array}{c}k \\
\left(s^{-0.5}\right)\end{array}$ & \multirow{2}{*}{$\begin{array}{c}t_{1 / 2} \\
(\mathrm{~min}) \\
200\end{array}$} & \\
\hline 0.001 & 0.905 & 0.910 & 0.955 & 0.989 & 0.00200 & & 62656 \\
\hline 0.002 & 0.936 & 0.950 & 0.429 & 0.975 & \multicolumn{2}{|c|}{0.00833} & 4202 \\
\hline 0.005 & 0.926 & 0.949 & 0.716 & 0.981 & \multicolumn{2}{|c|}{0.0121} & 2028 \\
\hline 0.008 & 0.924 & 0.950 & 0.00198 & 0.969 & \multicolumn{2}{|c|}{0.0143} & 1587 \\
\hline \multirow{3}{*}{$\begin{array}{c}\mathrm{Na}_{2} \mathrm{CO}_{3} \\
\text { Concentration } \\
\left(\mathrm{mol} \mathrm{L}^{-1}\right)\end{array}$} & Zeroth & First & Parabolic & \multirow{2}{*}{\multicolumn{4}{|c|}{ Pseudo second Order }} \\
\hline & Order & Order & Diffusion & & & & \\
\hline & \multicolumn{3}{|c|}{$r^{2}$} & $r^{2}$ & $\begin{array}{c}\mathrm{k} \\
\left(\mathrm{mg}^{-1} \mathrm{Ls}^{-1}\right)\end{array}$ & \multicolumn{2}{|l|}{$\begin{array}{c}t_{1 / 2} \\
(\min )\end{array}$} \\
\hline 0.001 & 0.461 & 0.492 & 0.697 & 0.999 & \multicolumn{2}{|c|}{0.00099} & 29 \\
\hline 0.002 & 0.405 & 0.436 & 0.636 & 1.000 & \multicolumn{2}{|c|}{0.00129} & 20 \\
\hline 0.005 & 0.341 & 0.395 & 0.565 & 1.000 & \multicolumn{2}{|c|}{0.00192} & 9 \\
\hline 0.008 & 0.207 & 0.304 & 0.409 & 1.000 & \multicolumn{2}{|c|}{0.00223} & 6 \\
\hline \multirow{3}{*}{$\begin{array}{c}\mathrm{Na}_{3} \mathrm{PO}_{4} \\
\text { Concentration } \\
\left(\mathrm{mol} \mathrm{L}^{-1}\right) \\
\end{array}$} & Zeroth & First & Parabolic & \multirow{2}{*}{\multicolumn{4}{|c|}{ Pseudo second Order }} \\
\hline & Order & Order & Diffusion & & & & \\
\hline & \multicolumn{3}{|c|}{$r^{2}$} & $r^{2}$ & \multicolumn{2}{|c|}{$\begin{array}{cc}\mathrm{k} & \dagger_{1 / 2} \\
\left(\mathrm{mg}^{-1} \mathrm{Ls}^{-1}\right) & (\mathrm{min}) \\
\end{array}$} & \\
\hline 0.001 & 0.505 & 0.546 & 0.734 & 1.000 & & & 345 \\
\hline 0.002 & 0.424 & 0.494 & 0.655 & 0.999 & & & 194 \\
\hline 0.005 & 0.413 & 0.506 & 0.645 & 0.999 & & & 126 \\
\hline 0.008 & 0.376 & 0.476 & 0.03 & 1.000 & & & 31 \\
\hline
\end{tabular}

Table 3 Rate constants, half-life $\left(t_{1 / 2}\right)$ and correlation coefficients obtained from-fitting of the data of DPPA release from DPPAEX into NaCl, $\mathrm{Na}_{2} \mathrm{CO}_{3}$ and $\mathrm{Na}_{3} \mathrm{PO}_{4}$ solutions [9]

\begin{tabular}{|c|c|c|c|c|c|c|}
\hline \multicolumn{7}{|c|}{ DPPAEX } \\
\hline \multirow[t]{2}{*}{$\begin{array}{c}\mathrm{NaCl} \\
\text { Concentration } \\
\left(\mathrm{mol} \mathrm{L}^{-1}\right)\end{array}$} & \multirow[t]{2}{*}{$\begin{array}{l}\text { Zeroth } \\
\text { Order }\end{array}$} & \multirow{2}{*}{$\begin{array}{r}\begin{array}{c}\text { First } \\
\text { Order }\end{array} \\
r^{2}\end{array}$} & \multirow[t]{2}{*}{$\begin{array}{l}\text { Pseudo- } \\
\text { second } \\
\text { Order }\end{array}$} & \multicolumn{3}{|c|}{ Parabolic Diffusion } \\
\hline & & & & $r^{2}$ & $\begin{array}{c}k \\
\left(s^{-0.5}\right)\end{array}$ & $\begin{array}{l}t_{1 / 2} \\
(\min )\end{array}$ \\
\hline 0.001 & 0.943 & 0.948 & 0.922 & 0.997 & 0.00251 & 40426 \\
\hline 0.002 & 0.990 & 0.994 & 0.148 & 0.938 & 0.0148 & 1732 \\
\hline 0.005 & 0.905 & 0.950 & 0.498 & 0.978 & 0.0186 & 895 \\
\hline 0.008 & 0.934 & 0.973 & 0.793 & 0.984 & 0.0190 & 891 \\
\hline \multirow{3}{*}{$\begin{array}{c}\mathrm{Na}_{2} \mathrm{CO}_{3} \\
\text { Concentration } \\
\left(\mathrm{mol} \mathrm{L}^{-1}\right)\end{array}$} & Zeroth & First & Parabolic & \multirow{2}{*}{\multicolumn{3}{|c|}{ Pseudo second Order }} \\
\hline & Order & Order & Diffusion & & & \\
\hline & \multicolumn{3}{|c|}{$r^{2}$} & $r^{2}$ & $\begin{array}{c}\mathrm{k} \\
\left(\mathrm{mg}^{-1} \mathrm{Ls}^{-1}\right)\end{array}$ & $\begin{array}{c}t_{1 / 2} \\
\text { (min) }\end{array}$ \\
\hline 0.001 & 0.545 & 0.618 & 0.772 & 0.997 & 0.000341 & 56 \\
\hline 0.002 & 0.254 & 0.288 & 0.464 & 1.000 & 0.00253 & 8 \\
\hline 0.005 & 0.236 & 0.267 & 0.438 & 1.000 & 0.00250 & 7 \\
\hline 0.008 & 0.248 & 0.309 & 0.458 & 1.000 & 0.00372 & 3 \\
\hline \multirow{3}{*}{$\begin{array}{c}\mathrm{Na}_{3} \mathrm{PO}_{4} \\
\text { Concentration } \\
\left(\mathrm{mol} \mathrm{L}^{-1}\right)\end{array}$} & Zeroth & First & Parabolic & \multirow{2}{*}{\multicolumn{3}{|c|}{ Pseudo second Order }} \\
\hline & Order & Order & Diffusion & & & \\
\hline & \multicolumn{3}{|c|}{$r^{2}$} & $r^{2}$ & $\begin{array}{c}\mathrm{k} \\
\left(\mathrm{mg}^{-1} \mathrm{Ls}^{-1}\right) \\
\end{array}$ & $\begin{array}{c}t_{1 / 2} \\
(\min )\end{array}$ \\
\hline 0.001 & 0.498 & 0.564 & 0.718 & 0.994 & 0.000585 & 99 \\
\hline 0.002 & 0.482 & 0.531 & 0.718 & 0.951 & 0.000213 & 78 \\
\hline 0.005 & 0.654 & 0.780 & 0.865 & 0.997 & 0.000206 & 38 \\
\hline 0.008 & 0.338 & 0.442 & 0.555 & 1.000 & 0.000122 & 12 \\
\hline
\end{tabular}


Table 4 Release order of DPPA from DPPADI and DPPAEX into various solutions

\begin{tabular}{ll}
\hline Nanocomposites & Solution \\
\hline DPPADI & $\mathrm{Cl}^{-}-\mathrm{CO}_{3}^{2-}-\mathrm{PO}_{4}^{3-}>\mathrm{PO}_{4}^{3-}>\mathrm{CO}_{3}^{2-}-\mathrm{PO}_{4}^{3-}>\mathrm{CO}_{3}{ }^{2-}>\mathrm{Cl}^{-}-\mathrm{PO}_{4}^{3-}>\mathrm{Cl}^{-}-\mathrm{CO}_{3}{ }^{2-}>\mathrm{Cl}^{-}$ \\
DPPAEX & $\mathrm{CO}_{3}{ }^{2-}>\mathrm{Cl}^{-}-\mathrm{CO}_{3}^{2-}-\mathrm{PO}_{4}^{3-}>\mathrm{PO}_{4}^{3-}>\mathrm{CO}_{3}^{2-}-\mathrm{PO}_{4}^{3-}>\mathrm{Cl}^{-}-\mathrm{CO}_{3}{ }^{2-}>\mathrm{Cl}^{-}-\mathrm{PO}_{4}^{3-}>\mathrm{Cl}^{-}$ \\
\hline
\end{tabular}

\section{Acknowledgement}

The authors are grateful for the research support from GPU Grant no. 2017-0188-101. NH thanks UPSI for their support for this research.

\section{References}

[1] Cavani, F., Triffiro, F. and Vaccani, A. 1991. Hydrotalcitetype Anionic Clays: Preparation, Properties and Application. Catalysis Today. 11: 173-30.

[2] Jin, S., Li, S., Wang, C., Liu, J., Yang, X., Wang, P. C., Zhang, $X$. and Liang, $X$. J. 2014 . Biosafe Nanoscale Pharmaceutical Adjuvant Materials. Journal of Biomedicine Nanotechnology. 10(9): 2393-2419.

[3] Wilkins, R. 2004. Controlled Release Formulation, Agricultural. Encyclopedia of Polymer Science and Technology, 2004.

[4] del Arco, M., Fernández, A., Martín, C. and Rives, V. 2009. Release Studies of Different NSAIDs Encapsulated in Mg,Al,Fe-hydrotalcites. Applied Clay Science. 42: 538-544.

[5] Hussein, M. Z., Rahman, A. N. S. S., Sarijo, S. H. and Zainal, Z. 2012. Synthesis of a Monophasic Nanohybrid for a Controlled Release Formulation of Two Active Agents Simultaneously. Applied Clay Science. 58(1): 60-66.

[6] Bruna, F., Pavlovic, I., Celis, R., Barriga, C., Cornejo, J. and Ulibarri, M. A. 2008. Organohydrotalcites as Novel Supports for the Slow Release of the Herbicide Terbuthylazine. Applied Clay Science. 42: 194-200.

[7] Reichle, W. T. 1986. Synthesis of Anionic Clay Minerals (Mixed Metal Hydroxides, Hydrotalcite). Solid State lonics. 22: 135-142.

[8] Constantino, V. R. L and Pinnavaia, T. J. 1995. Basic Properties of $\mathrm{Mg} 2+1-x \mathrm{Al} 3+\mathrm{x}$ Layered Double Hydroxide Intercalated by Carbonate, Hydroxide, Chloride and Sulphate lons. Inorganic Chemistry. 34: 883-892.

[9] Hussein, M. Z., Hashim, N., Yahaya, A. H. and Zainal, Z. 2011. Synthesis of Dichlorprop-Zn/Al-hydrotalcite Nanohybrid and its Controlled Release Property. Sains Malaysiana 40(8): 887-896.

[10] Sato, T and Okuwaki, A. 1991. Intercalation of Benzenecarboxylate lons into the Interlayer of Hydrotalcite. Solid State Ionics. 45: 43-48.
[11] Ulibarri, M. A., Pavlovic, I., Hermosín, M. C. and Cornejo, J. 1995. Hydrotalcite-like Compounds as Potential Sorbents of Phenols from Water. Applied Clay Science. 10(1-2): 131145.

[12] Hussein, M. Z., Z. Zainal, Yahaya, A. H. and Foo, D. W. V. 2002. Controlled Release of Plant Growth Regulator ANaphthalane-Acetate from the Lamella of Zn-Al-Layered Double Hydroxide Nanocomposite. Journal of Controlled Release. 82: 417-427.

[13] Kura, A. U., Samer, H. H. A. A., Hussein, M. Z. and Fakurazi, S. 2014. Preparation of Tween 80-Zn/Al-Levodopa-Layered Double Hydroxides Nanocomposite for Drug Delivery System. Scientific World Journal. 2014.

[14] Qiu, H., LV, L., Pan, B. C., Zhang, Q. J., Zhang, W. M. and Zhang, Q. X. 2009. Critical Review in Adsorption Kinetic Models. Journal of Zhejiang University-Science A. 10(5): 716-724.

[15] Costa, P. and Lobo, J. M. S. 2001. Modeling and Comparison of Dissolution Profiles. European Journal of Pharmaceutical Sciences. 13(2): 123-133.

[16] Saifullah, B., Hussein, M. Z., Hussein-Al-Ali, S., Arulselvan, $H$. P. and Fakuraz, i S. 2013. Sustained Release Formulation of an Anti-tuberculosis Drug based on Para-aminosalicylic Acid-zinc Layered Hydroxide Nanocomposite. Chemistry Central Journal. 7(72): 1-11.

[17] Hashim, N., Hussein, M. Z., Isa, I. M., Kamari, A., Mohamed, A., Jaafar, A. M. and Taha, H. 2014. Synthesis and Controlled Release of Cloprop Herbicides from ClopropLayered Double Hydroxide and Cloprop-Zinc-Layered Hydroxide Nanocomposites. Open Journal of Inorganic Chemistry. 4(1): 9.

[18] Kong, X., Shi, S., Han, J., Zhu, F., Wei, M. and Duan, X. 2010. Preparation of Glycy-I-Tyrosine Intercalated Layered Double Hydroxide Film and Its in Vitro Release Behavior. Chemical Engineering Journal. 157: 598-604.

[19] Miyata, S. 1980. Physico-chemical Properties of Synthetic Hydrotalcites in Relation to Composition. Clays and Clay Minerals. 28(1): 50-56.

[20] Braterman, P. S., XU, Z. P. and Yarberry, F. 2004. Layered Double Hydroxide (LDHs). Marcel Dekker, Inc. USA. 373508.

[21] Hussein, M. Z., Hashim, N., Yahaya, A. H. and Zainal, Z. 2009. Controlled Release Formulation of Pesticide Agrochemical Based on 4-(2,4-dichlorophenoxy)butyrate Nanohybrid. Journal of Nanoscience and $\begin{array}{lll}\text { Nanotechnology. } & 9(3): & 2140-2147\end{array}$ 